\title{
Retraction Note to: Randomized controlled trial testing weight loss and abdominal obesity outcomes of moxibustion
}

\author{
Ching-Hsiu Hsieh ${ }^{1 *}$, Chi-Chuan Tseng ${ }^{2}$, Ju-Yu Shen ${ }^{3}$ and Pei-Ying Chuang ${ }^{4}$
}

\section{The original article can be found online at https://doi. org/10.1186/s12938-018- 0571-8.}

${ }^{*}$ Correspondence: chinghsiuh@yahoo.com; chinghsiuh@hotmail.com

1 Department of Nursing, Chang Gung University of Science and Technology, ChiayiCampus: 2, Chia-pu Rd, West Sec. Pu-tz, 613 Chia-Yi, Taiwan

Full list of author information is available at the end of the article

\section{Retraction to: BioMed Eng OnLine 2018, 17(Suppl 2):149 https://doi.org/10.1186/s12938-018-0571-8}

The Editors-in-Chief have retracted this article [1] because, after publication, concerns were raised regarding the study design and statistical analysis. Post-publication review has confirmed firstly that within-group changes were highlighted rather than betweengroup differences as appropriate for a randomized trial, and secondly that there are baseline differences between the groups that exist despite randomization for which analyses were not controlled. The data reported in this article are therefore unreliable. Ching-Hsiu Hsieh and Pei-Ying Chuang agree with this retraction. Chi-Chuan Tseng and Ju-Yu Shen have not responded to any correspondence from the publisher about this retraction.

\footnotetext{
Author details

${ }^{1}$ Department of Nursing, Chang Gung University of Science and Technology, ChiayiCampus: 2, Chia-pu Rd, West Sec. Pu-tz, 613 Chia-Yi, Taiwan. ${ }^{2}$ Department of Traditional Chinese Medicine Chang, Gung Memorial Hospital, Chia-Yi, Taiwan. ${ }^{3}$ Department of Early Childhood Educare, Tainan University of Technology, Tainan, Taiwan. ${ }^{4}$ School of Nursing, University
} of Maryland School of Nursing, Baltimore, MD, USA.

Published online: 24 January 2020

Reference

1. Hsieh CH, Tseng CC, Shen JY, Chuang PY, et al. Randomized controlled trial testing weight loss and abdominal obesity outcomes of moxibustion. BioMed Eng OnLine. 2018;17(Suppl 2):149. https://doi.org/10.1186/s1293 8-018-0571-8

\section{Publisher's Note}

Springer Nature remains neutral with regard to jurisdictional claims in published maps and institutional affiliations. source, provide a link to the Creative Commons licence, and indicate if changes were made. The images or other third party material in this article are included in the article's Creative Commons licence, unless indicated otherwise in a credit line to the material. If material is not included in the article's Creative Commons licence and your intended use is not permitted by statutory regulation or exceeds the permitted use, you will need to obtain permission directly from the copyright holder. To view a copy of this licence, visit http://creativecommons.org/ licenses/by/4.0/. The Creative Commons Public Domain Dedication waiver (http://creativecommons.org/publicdomain/zero/1.0/) applies to the data made available in this article, unless otherwise stated in a credit line to the data. 